This item was submitted to Loughborough's Research Repository by the author.

Items in Figshare are protected by copyright, with all rights reserved, unless otherwise indicated.

\title{
'Running a studio's a silly business': work and employment in the contemporary recording studio sector
}

PLEASE CITE THE PUBLISHED VERSION

http://dx.doi.org/10.1111/area.12037

\section{PUBLISHER}

(c) Royal Geographical Society (with the Institute of British Geographers). Published by Wiley.

\section{VERSION}

AM (Accepted Manuscript)

\section{PUBLISHER STATEMENT}

This work is made available according to the conditions of the Creative Commons Attribution-NonCommercialNoDerivatives 4.0 International (CC BY-NC-ND 4.0) licence. Full details of this licence are available at: https://creativecommons.org/licenses/by-nc-nd/4.0/

\section{LICENCE}

CC BY-NC-ND 4.0

\section{REPOSITORY RECORD}

Watson, Allan. 2019. "'running a Studio's a Silly Business': Work and Employment in the Contemporary Recording Studio Sector”. figshare. https://hdl.handle.net/2134/21402. 
"Running a studio's a silly business": work and employment in the contemporary recording studio sector

\author{
Allan Watson \\ Department of Geography, Staffordshire University \\ Science Centre, Leek Road \\ Stoke-on-Trent, Staffordshire \\ ST4 2DF, UK \\ a.watson@staffs.ac.uk
}




\section{"Running a studio's a silly business": work and employment in}

\section{the contemporary recording studio sector}

\section{Abstract}

This paper is concerned with work and employment in the recording studio sector of the contemporary musical economy. More specifically, it aims to begin to address the lack of attention paid to the issue of individual subjectivity in the cultural workplace, through an empirically-informed account of how the changing economic conditions in the recording studio sector are impacting on work as seen from the perspective of those working in the sector. The sector is one marked by a continued move towards more temporary and flexible forms of project working, as seen in the comparatively recent development of a freelance project-based model for recording. For record producers and studio engineers, these developments have impacted negatively upon employment relations, working conditions and job security. Recent developments in digital technologies, which have resulted in a crisis of reproduction in the musical economy, have further heightened the importance of these issues. Drawing on qualitative interviews with record producers and engineers working in recording studios in London, the paper highlights how the rise of freelance work has resulted in a precarious work environment that has shifted the pressure of obtaining work, and the financial risk of not doing so, on to individual producers and engineers, and at the same time resulted in exhausting yet bulimic work regimes. Both for new and experienced producers and engineers, the sector is revealed as an increasingly difficult one in which to find and maintain gainful employment; for many, it is an increasingly exploitive one. Yet, the individuality afforded to producers and engineers by digital technologies, and the potential 
symbolic and financial rewards on offer to those who can successfully follow a career in music production, means that it remains an attractive and much sought after career.

Key words: Recording studio; freelance labour; precarious labour; exploitation; London; qualitative interviews

\section{Introduction}

Running a studio's a silly business. I don't recommend it to anyone. (Interview 17, male engineer-producer, forties).

...if you were come to me today and say look I'm thinking of opening a studio I would say under any circumstances don't even consider it. (Interview 16, male engineer, fifties)

Since as early as the 1950 s, developments in musical tastes and recording technologies have been challenging the economic viability of the recording studio sector of the musical economy. As new styles of popular music altered the marketplace for recording music, the large, stable company-owned facilities and the centralised in-house production that marked the early days of music recording would give way to outside, entrepreneurial producers (Théberge 2012). At the same time, developments in recording technologies and practices would reduce the need for larger studios and allow these producers to open their own 'project' studios, a development which posed a significant economic challenge to established studios. These developments resulted in the rise of temporary and flexible patterns of freelance-based project work (see Lorenzen and Frederickson 2005; Watson 2012) marked by 
volatile and insecure employment, low wages, and long working hours, whilst also increasing the potential financial rewards amongst those record producers who reach 'star' status.

In the 1990s, developments in software and digital technologies would further impact on the economic sustainability of the global music industry. In particular, issues around intellectual property rights and the illegal distribution of digital music (see see Leyshon 2001; 2003; Leyshon et al. 2005) would tip a music industry already on the verge of crisis into a full-blown crisis of reproduction (Leyshon 2009) and result in a crisis of funding throughout the wider musical economy. With specific regard to the recording studio sector, these technological developments have had two major direct impacts (see Leyshon 2009).

Firstly, the falling recording budgets of record companies have resulted in severe economic pressures for studios, and in particular on larger recording studios that have traditionally relied on recording projects commissioned and funded by these companies. Second, the development of low-cost software technologies has allowed musicians to produce high-quality recordings in home studios (Hracs 2012). These two factors Leyshon argues have contributed to the reduced demand for studio time, resulting in "a spate of studio closures, redundancies, and underemployment within musical agglomerations" $(2009,1309)$. However, while studio closures do seem to be widespread, this needs to be balanced against increased opportunities for individual producers to run their own smaller project studios. Théberge (2012), for example, reports data from the US census that shows an increase both in the number of commercial studios and people involved in sound recording between 1997 and 2002. 
One outcome of the crisis in the music industry that cannot be quantitatively measured however is the heightening of the employment insecurity that was already pervasive in the sector. This is a development which mirrors changes in the contemporary creative and media industries more widely (see McRobbie 2002; McGuigan, 2010); poor pay, long hours, bulimic patterns of working, and profound experiences of insecurity and anxiety about finding work, al recognised characteristics of these industries (Jones 1996; Gill and Pratt 2008; Hesmondhalgh and Baker 2010). For Entwistle and Wissinger, this type of work places considerable demands upon workers in terms of their "self-reliance and resourcefulness" $(2006,782)$. In the recording studio sector, this is best illustrated through the 'entrepreneurial' producer or engineer who must increasingly not only perform creative tasks, but also a range of business tasks including searching for work, self-marketing and managing the finances of small studio facilities. This mirrors the increased entrepreneurialism found amongst independent musicians (see Coulson 2012; Hracs 2012, 2013).

While in recent years a body of literature has emerged which considers issues of freelance work and employment insecurity across the creative and media industries (see for example Arvidsson et al. 2010; Blair 2001, 2009; Blair et al. 2001, 2003; Christopherson 2002, 2004; Dex et al. 2000; Gill 2002; Henninger and Gottschall 2007; Hesmondhalgh and Baker 2010, 2011; Lee 2011), cultural workplace studies remain rare. For Banks (2007), corresponding with the general neglect of the labour process has been a "lack of attention paid to the issue of individual subjectivity in the cultural workplace" $(2007,27$, emphasis in original), that is to say a disregard of the 'worker-as-subject'. It is the subjective issues around work and employment, rather than the economics of the decline of the sector per se (an excellent anatomy of which has already been provided by Leyshon 2009) with which this paper is concerned. The aim of the paper is to begin to address the "surprising lack of 
qualitative studies of working conditions in the cultural industries" (Hesmondhalgh and Baker 2010, 5) in order to extend current understandings of the conditions and politics of work in the cultural and creative economy forward. It aims to do this through an empiricallyinformed account of how the changing economic conditions in the recording studio sector are impacting on work and employment, as seen from the perspective of those working in the sector.

Following a brief methodological discussion, the paper outlines the changing employment relations in the sector and the factors driving the rise in freelance working. In particular, the discussion focuses on employment uncertainty and the precarious nature of work in the sector. Following this, the paper considers the related issues of exploitation, exhausting work regimes and internships. The paper then moves on to discuss the rewards of studio work and questions the viability of careers in the sector.

\section{Methodology}

The discussion presented in the paper is based upon empirical data from 19 semi-structured interviews, undertaken with record producers and recording engineers working in recording studios in London, between June 2010 and March 2011. All interviewees were male, reflecting the fact that music production and recording engineering remain almost exclusively male forms of employment. Interviewees were from a range of employment categories (freelance, contracted to a recording studio, or owner-operator of a studio) and worked in studios that ranged from very small project studios to large internationally-renowned recording facilities. 
All interviews were undertaken using a common schedule of questions, but with flexibility to explore interesting issues that emerged in discussion. A range of questions were asked regarding technology and technical work, creative collaboration, employment and the economy of the sector, and networking. Interviews lasted between 30 minutes and 2 hours, resulting in a total of almost 18 hours of recorded data. All interviews were recorded and transcribed, and transcripts were subsequently analysed using systematic coding and recoding based around key themes and common categories emerging from the data, considered in relation to the overall theoretical framework.

Particular questions around employment relations, working hours, and pay were recognised as potentially sensitive given the importance of these factors in shaping the working and personal lives of the interviewees. In many cases, questions invoked quite strong and often emotional responses. Furthermore, given my 'outsider' position as an academic with no experience of working in the sector, there was the potential for interviewees to respond in a way that they felt fitted particular stereotypes and popular conceptions of work in the sector. Care therefore needed to be taken when analysing the responses of the interviewees to particular questions. Accounts given of extremely long working hours, for example (up to 120 hours per week in some cases), may or may not be reliable.

\section{Changing employment relations and the growth of employment uncertainty}

As Leyshon (2009) details, employment in the recording studio sector before the 1970s was dominated by bureaucratic careers, with producers and engineers working as salaried employees of recording studios. However, since the 1970s, there has been a shift amongst producers and engineers to freelance status. This, Leyshon argues, was driven in part by the 
growing celebrity status of some producers, and the possibility of making much more money than the relatively modest incomes on offer to producers and engineers contracted to studios, as well as by the growth in the number of independent studios. The trend towards freelancing has been given fresh impetus more recently by developments in affordable computer-based recording technologies that have facilitated the growth of small 'project' studios and home studios (Leyshon 2009).

Contracted salaried positions are now rare in the recording studio sector. This is the case even in the largest of studios, which have recently been moving towards more flexible and freelance models of employment. What has developed is a new relationship between employee and employer in which employers no longer accept responsibility for the employment and development of the workforce, but rather have a relationship with the employee that is transactional, contractual and short-term (see du Gay et al. 1996). In 2006, for example, Air Studios, a major studio in North-West London, took all of their recording engineers off the studio payroll, effectively forcing them to become freelance. As Leyshon (2009) describes, many engineers, particularly in larger studios, are now classed as 'retained' staff, getting paid a small salary to be available to work for the studio, with their pay increasing when there is work to do, which is funded out of the fees paid by the client. When not working at the studio at which they are retained, they act as freelance engineers, obtaining work at other studios.

This situation has led to the development of new employment relations between retained and freelance engineers and recording studios: where engineers gain work, they bring projects to that particular studio, and where the studio gains work they will recommend that particular engineer. Such strategies then aim to draw a competitive advantage from the 
network of contacts and industry reputation of both parties. However, while such arrangements might suggest something of a symbiotic relationship, these new employment relations are often balanced unevenly towards recording studios. In paying staff a retainer only or moving staff on to freelance contracts, the financial risks of not obtaining work are effectively passed to the workforce (Dex et al. 2000), leaving individuals with a heightened level of responsibility for their individual destinies, but in an "ambiguous position vis-à-vis power to determine them" (Ekinsmyth 2002, 239; see also Ekinsmyth 1999).

The demands being placed on self-reliance and resourcefulness by these changing employment relations go hand-in-hand with short tenure employment and constant employment uncertainty; that is to say it is 'precarious' employment (see Murdock 2003; Neilson \& Rossiter 2005; Ross 2008) marked by "structured job insecurity" (Blair et al. 2001, 174). In such a precarious work environment, job seeking becomes relentless in order to sustain sufficient employment (Patterson 2001), and there is the periodic risk of being out of work (Neff et al. 2005); as one interviewee noted how it can be "suddenly three months with nothing, which you know if you don't have a lot of backing it goes quickly, the money you do have" (Interview 13, male engineer-producer, forties). This type of precarious employment is of course not unique to the recording studio sector or the music industry, rather it is a noted characteristic of employment in the creative industries more generally (see Gill and Pratt 2008; also Murdock 2003), as well as in other project-based industries (see for example Vinodrai 2006) and in industries where temporary contracts are common (see for example McDowell et al. 2009).

As Banks (2007) notes, workers navigating the precarious terrain of a more flexible economy must often juggle multiple jobs; when studio work is not available, it is often 
necessary for producers and engineers to find alternative incomes. Amongst those engineers who were not able to maintain themselves financially on studio work alone, there were a number of different types of employment taken to supplement income. For some, supplementary employment was broadly related to their 'core' studio work, for example working in retail outlets specialising in musical equipment and teaching on music production courses. For others, relatively unrelated yet very flexible home-based work (such as marking exam scripts for examination boards) was seen as a way to supplement income without disrupting their key focus on the core work. For a few, studio work was not their core work but rather work which fitted around a more stable 'day job'. Such a position is an uncomfortable one for many in respect to their 'identity' vis-à-vis other producers and engineers, in that taking on more conventional 9-5 work is often regarded as 'selling out':

"So I've had to well, sell-out some people may say, or find other ways to supplement my income because essentially working as an engineer, especially when you're working, when your work comes through a studio, it is very difficult to earn a lot of money..." (Interview 10, male engineer, thirties)

\section{Exhausting work regimes and exploitation}

Bulimic patterns of working in which "idle periods with no work can give way to periods that require intense activity" (Gill and Pratt 2008, 17) are common in studio work. Periods which are light on work, resulting in little or no pay for retained and freelance engineers, are mirrored by periods of punishing overwork when studios are busy (Leyshon 2009). Such work regimes are extremely demanding on producers and engineers, affecting the engineers both mentally and physically, and often having a very damaging impact on personal 
relationships away from the studio environment. As Gill and Pratt suggest, the extraordinarily long hours worked by cultural workers as part of stop-go bulimic patterns of working often exerts a heavy cost on, or even prohibits, relationships outside work with friends, partners, and families, and has "attendant impacts on sleep, diet, health and social life" $(2008,17)$. One engineer explained how "I've seen loads of people whose relationships have been killed by it", going to say of his relationship with his own girlfriend, "it's come pretty close with us as well" (Interview 8, male engineer, twenties). Another engineer, who now owns his own private studio, explained his experiences of coping with the demands of a freelance engineering: "...I was freelancing at the [studio name omitted] for a couple of years and then I didn't exactly have a nervous breakdown, I had a physical breakdown... I overdid it, and it completely destroyed me" (Interview 17, male engineer-producer, forties).

This exhausting work regime is often met with relatively poor financial rewards, especially for engineers. As Leyshon (2009) describes, engineers receive relatively low salaries, suggesting that in $2005 / 06$ the average starting salary for an engineer in central London was $£ 12,000$, about half national average annual earnings. Moreover, the contracts of engineers can be quite exploitive, often resulting in engineers not being paid for all of the hours they work. One interviewee described his own experiences of this:

...we were really take advantage of quite a lot, where there was all sorts of dubious practice going on... you got paid for 150 hours a month which is quite a lot, but you only got overtime after 200 hours. So it was a big 50 hour block which you wouldn't get paid for. (Interview 8, male engineer, twenties) 
Perhaps the starkest examples of exploitation found in the sector relate to the informal internships taken by those looking to begin a career in the recording studio sector. In recent times, the massification of higher education, in particular in music technology courses, has filled a gap left by a lack of the apprentices previously found in larger studios (Théberge 2012) and created a new post-degree vocational need (Guile 2009) because although studying for a degree provides a grounding for new entrants to the labour market, it rarely provides an "expectation or understanding of what was required in vocational contexts" (Raffo et al. 2000: 223). Many prospective engineers accept that the best way to secure an early foothold in the recording studio sector is to participate in unpaid activities, essentially providing free labour which becomes 'masked' in the form of 'internships' (Holt and Lapenta 2010). Competition is fierce even though many positions do not involve payment; as one interviewee described, "the amount of CVs that come in from people who are happy to work for absolutely no money at all is quite amazing" (Interview 10, male engineer, thirties).

One interviewee, reflecting on the growing number of sound engineering/music technology courses being offered by Universities, stated that "I do worry about a lot of these media courses because I, these poor kids are doing three-year courses on something they should be doing in the evenings around something solid... to come out and expect to have a job is very silly" (Interview 12, male engineer-producer, forties). Another interviewee, a veteran studio engineer with experience in training young engineers, described how he has to explain the demands of the role to young aspiring engineers:

"Normally I read the riot act to young people that come in, students. And I say to them, basically, write-off the next two years of your life... short of you dying, short of you actually getting married on that day... or you're incapacitated by being knocked 
down by a car or whatever, there are no other excuses that you cannot work when the work is there." (Interview 5, male engineer, sixties)

\section{The rewards of studio work}

However, while there are many examples of 'chronic exploitation' (McGuigan 2010) in the sector, it is important to note that the situation is much more complicated than one of simple exploitation (see Hesmondhalgh 2010). As Terranova argues, this 'free labour' is "simultaneously voluntarily given and unwanted, enjoyed and exploited" (2004: 74), and there exists an intimate connection between the process of subjectification and subjection (Ursell 2000). The question then becomes one of why, despite high levels of employment uncertainty and often exploitive and exhausting work regimes, people continue to want work in the recording studio sector. If one looks to the literature, it is frequently suggested that cultural work is invariably more than a job; rather it is a labour of love. Therefore, as Hesmondhalgh and Baker (2010) assert, pleasure in work is closely linked to selfexploitation.

Much like is found in other creative sectors, record producers and engineers have a strong creative and emotional attachment to their work. For many, the main 'reward' from their work is not money (as noted earlier, pay is often relatively poor) but from the chance to make music: 
“... it is rewarding and I mean I wouldn't be in it for any other reason, the pay is really poor enough that the main reason I have for sticking with it is because I actually make music on a daily basis which is a dream... (Interview 10, male engineer, thirties)

This is not to say that financial reward is unimportant, however. Indeed, in the recording sector, there is the prospect of high financial reward for those whose work obtains notable commercial success; much as is found in the creative industries more widely (Taylor and Littleton, 2008). In the case of two of the interviewees, commercial success had brought enough financial reward to allow them to invest money in building their own recording facilities. Financial reward is an important incentive for those working in the sector.

Producers and engineers perform both technical and creative roles in the studio, and many of the interviewees noted that they prided themselves on their high levels of technical competency and knowledge. Reward then also comes from the knowledge of a 'job well done' in a technical sense, as well as often in overcoming the engineering challenges that particular recording projects present, and the often varied nature of projects:

“... every new session is a challenge for me and that's what I enjoy about it. If I was doing the same thing day in, day out I think I'd get bored to be honest with you. (Interview 1, male engineer, thirties)

For many producers and engineers, it is clear that their work plays a significant part in how they define themselves as individuals. Some interviewees recognised that there job was generally seen by outsiders as being 'cool' and suggested they played on this in social settings (for example 'name-dropping' famous clientele), while others valued being part of 
'insider' communities of 'audiophiles' and technical 'geeks'. In these ways, work becomes a central part of the individualized identity projects and life narratives (see Giddens 1991) of these individuals.

\section{Questioning the viability of careers in the recording studio sector}

Such positive experience of work are however tempered by the expectation of high levels of uncertainty and insecurity surrounding employment, and associated exhausting work regimes - arguably the major forces shaping work lives in project-based creative and media industries (see Christopherson 2002). Ross notes that while a few cultural workers will thrive under these conditions, "most will subsist, neither as employers or employees, in a limbo of uncertainty, juggling their options, massaging their contacts, never knowing where their next project or source of income is coming from" (Ross 2008, 36). The resultant cycle of "feast and famine', Ross argues, is familiar to anyone whose livelihood folds into the creative economy.

For Dex et al. (2000) the extent to which individuals are able to cope with this uncertainty will influence the viability of cultural and creative workforces to sustain their potential and quality of the product in a wide range of project-based creative industries. Indeed, the low salaries and exhausting regimes associated with being a recording engineer were cited by some of the interviewees as reasons why, despite the many rewarding aspects of their work, they were considering career changes. There were two interviewees who were particularly candid in their discussions regarding making this decision. Both were male engineers in their thirties, and both retained to particular studios, one on a part-time basis and another on a full-time basis. The first interviewee, who held a part-time job outside of the 
recording sector alongside his part-time work as a recording engineer, explained how the decision to start a family had caused him to re-think his career as an engineer, due to the need to earn more money to support a family:

"... a thing I'm going through at the moment actually is working out whether I can carry on doing this. Actually just recently I've got a full time job now [outside the music industry], so I'm going to have to cut back on the stuff I'm doing here, which is not ideal from a long-term being an engineer point of view, but to be honest the money side of it is going to be better so I'm going to be more comfortable and more able to pay my bills. We're expecting a child in December so..." (Interview 14, male engineer, thirties)

The second interviewee had spent his career as an engineer at a successful and well-reputed recording studio, and as such felt he had been quite privileged in terms of working on commercially successful recording projects with high-profile musicians and producers. However, rather than inspiring him to further develop his career and reputation to emulate these producers, observing them within and outside of the studio environment had made him question the value, both economically and personally, or pursuing the career into his forties. He describes how:

"I've worked with a lot of really successful producers and engineers and people who've been in the industry for a lot longer than I have and all of them without fail, have usually dysfunctional home lives. They're usually ill, they usually have really bad diets, they have alcohol problems, drug problems and all kinds of stuff. None of them have made that much money, it's not like I'm interested in really making loads 
of money, but enough money to survive. And so you kind of think, well hang on, if I stay around for another ten years... if you look at the people who are at that level you would end up at, you kind of go, well, do I actually want to be like that?" (Interview 15 , male engineer, thirties)

\section{Conclusion}

Building on earlier geographical accounts of the recording studio sector (Gibson 2005; Leyshon 2009) and recent literature on work and employment in the creative and media industries, this paper has considered the subjective experiences of record producers and engineers of employment relations and working conditions in the recording studio sector of the musical economy. The paper has highlighted the ways in which contemporary economic challenges have heightened the uncertain nature of work that have long been prevalent in the sector. New employment strategies are balanced unevenly towards recording studios, moving the pressure of obtaining work, and the financial risk of not doing so, away from the studio management and on to producers and engineers. As such, these new employment relations are characterised by constant employment uncertainty for freelance studio workers. This uncertainty is often combined with punishing yet bulimic work regimes which are rewarded, for many, with little or no pay. Both for new and experienced producers and engineers, the sector is revealed as an increasingly difficult one in which to find and maintain gainful employment, and for many an increasingly exploitive one. Yet, the individuality afforded to producers and engineers by digital technologies, and the potential symbolic and financial rewards on offer to those who can successfully follow a career in music production, means that it remains an attractive and much sought after career. 


\section{References}

Arvidsson A, Malossi G and Naro S (2010) Passionate work? Labour conditions in the Milan fashion industry Journal for Cultural Research 14 (3) 295-309

Banks M 2007 The Politics of Cultural Work Palgrave Macmillan, Basingstoke

Blair H 2001 You're only as good as your last job: the labour process and labour market in the British Film Industry Work, Employment and Society 15 (1) 149-169

Blair H 2009 Active networking: action, social structure and the process of networking in McKinlay A and Smith $\mathbf{C}$ eds Creative Labour: Working in the Creative Industries Palgrave Macmillan, Basingstoke

Blair H, Culkin N and Randle K 2003 From London to Los Angeles: a comparison of local labour market processes in the US and UK film industries The International Journal of Human Resource Management 14 (4) 619-633

Blair H, Grey S and Randle K 2001 Working in film: employment in a project based industry Personnel Review 30 (2) 170-185

Boggs J S and Rantisi N M 2003 The 'relational turn' in economic geography Journal of Economic Geography 3 109-116

Christopherson S 2002 Project work in context: regulatory change and the new geography of media Environment and Planning A 34 2003-2015

Christopherson S 2004 The divergent worlds of new media: how policy shapes work in the creative economy Review of Policy Research 21 (4) 543 - 558

Coulson S 2012 Collaborating in a competitive world: musicians' working lives and understandings of entrepreneurship Work Employment and Society 26 (2) 246-261 
Dex S, Willis J, Peterson R and Sheppard E 2000 Freelance workers and contract uncertainty: the effects of contractual changes in the television industry Work, Employment \& Society 14 (2) 283-305

Du Gay P, Salaman G and Rees B 1996 The conduct of management and the management of conduct: contemporary managerial discourse and the constitution of the 'competent' manager Journal of Management Studies 33 263-282

Ekinsmyth C 1999 Professional workers in a risk society Transactions of the Institute of British Geographers 24 (3) 353-366

Ekinsmyth C 2002 Project organization, embeddedness and risk in magazine publishing Regional Studies 36 (3) 229-243

Entwistle J and Wissenger E 2006 Keeping up appearances: aesthetic labour in the fashion modelling industries of London and New York The Sociological Review 54 (4) 774 - 794 Gibson C 2005 Recording studios: relational spaces of creativity in the city Built Environment 31 (3) 192-207

Giddens A 1991 Modernity and Self-Identity: Self and Society in the Late Modern Age. Polity, Cambridge

Gill R 2002 Cool, creative and egalitarian? Exploring gender in project-based new media work in Europe Information, Communication and Society 5 (1) 70-89

Gill R and Pratt A C 2008 In the social factory? Immaterial labour, precariousness and cultural work Theory, Culture and Society 25 (7-8) 1-30

Guile D 2009 Conceptualising the transition from education to work as vocational practice: lessons from the UK's creative and cultural sector British Educational Research Journal 35 (5) $761-779$ 
Hesmondhalgh D 2010 User-generated content, free-labour and the cultural industries Ephemera $10(3 / 4)$ 267-284

Hesmondhalgh D and Baker S 2010 “'A very complicated version of freedom': conditions and experiences of creative labour in three cultural industries" Poetics 38 4-20

Hesmondhalgh D and Baker S 2011 Creative Labour: Media Work in Three Cultural Industries. Routledge, London

Holt F and Lapenta F 2010 Introduction: autonomy and creative labour Journal for Cultural Research 14 (3) 223-229

Hracs, B J 2012 A creative industry in transition: the rise of digitally driven independent music production Growth and Change 43 (3) 442-461

Hracs, B J 2013 Cultural intermediaries in the digital age: the case of independent musicians and managers in Toronto Regional Studies DOI: 10.1080/00343404.2012.750425

Jones C 1996 Careers in project networks: the case of the film industry in Arthur M B and Rousseau D M eds The Boundaryless Career: A New Employment Principle for a New Organizational Era Oxford University Press, Oxford

Jones S 2002 Music that moves: popular music, distribution and network technologies Cultural Studies 16 (2) 213-32

Lee D 2011 Networks, cultural capital and creative labour in the British independent television industry Media, Culture and Society 33 (4) 549-565

Leyshon A 2001 Time-space (and digital) compression: software formats, musical networks, and the reorganization of the music industry Environment and Planning A 33 (1) 49-77 Leyshon A 2003 Scary monsters? Software formats, peer-to-peer networks, and the spectre of the gift Environment and Planning D 21 (5) 533-558 
Leyshon A 2009 The software slump?: digital music, the democratization of technology, and the decline of the recording studio sector within the musical economy Environment and Planning A 41 1309-1331

Leyshon A, Webb P, French S, Thrift $\mathbf{N}$ and Crewe $\mathbf{L} 2005$ On the reproduction of the musical economy after the Internet" Media, Culture and Society 27 177-209

Lorenzen $\mathbf{M}$ and Frederiksen $\mathbf{L} 2005$ The management of projects and product experimentation: examples from the music industry European Management Review 2 (3) $198-211$

McDowell L, Batnitzky A and Dyer S 2009 Precarious work and economic migration: emerging immigrant divisions of labour in Greater London's service sector International Journal of Urban and Regional Research 33 (1) 3-25

McGuigan J 2010 Creative labour, cultural work and individualisation International Journal of Cultural Policy 16 (3) 323-335

McRobbie A 2002 Clubs to companies: notes on the decline of political culture in speeded up creative worlds Cultural Studies 16 (4) 516-531

Murdock G 2003 Back to work: cultural labour in altered times in Beck A ed Cultural Work: Understanding the Cultural Industries Routledge, London

Neff G, Wissenger E and Zukin S 2005 Entrepreneurial labor among cultural producers: “cool" jobs in "hot" industries Social Semiotics 15 307-334

Neilson B and Rossiter N 2005 From precarity to precariousness and back again: labour, life and unstable networks Fiberculture 5, no pagination

Patterson R 2001 Work histories in television Media, Culture \& Society 23 495-520 
Raffo C, O'Connor J, Lovatt A and Banks M 2000 Attitudes to formal business training amongst entrepreneurs in the cultural industries: situated business learning through 'doing it with others" Journal of Education and Work 13 (2) 215-230

Ross A 2008 The new geography of work: power to the precarious? Theory, Culture and Society 25 (7-8) 31-49

Storey J, Salaman G and Platman K 2005 Living with enterprise in an enterprise economy: freelance and contract workers in the media Human Relations 58 (8) 1033-1054

Tankel J D 1990 The practice of recording music: remixing as recording Journal of Communication 40 (3) 34-46

Taylor S and Littleton K 2008 Art work or money: conflicts in the construction of a creative identity The Sociological Review 56 (2) 275-292

Terranova T 2004 Network Culture: Politics of the Information Age Pluto Press, London Théberge P 2012 The end of the world as we know it: the changing role of the studio in the age of the internet in Frith $\mathbf{S}$ and Zagorski-Thomas $\mathbf{S}$ eds The Art of Record Production: An Introductory Reader for a New Academic Field Ashgate, Farnham

Ursell G 2000 Television production: issues of exploitation, commodification and subjectivity in UK television labour markets Media, Culture and Society 22 805-825

Vinodrai T 2006 Reproducing Toronto's design ecology: career paths, intermediaries, and local labor markets Economic Geography 82 (3) 237-263

Watson A 2012 The world according to iTunes: mapping urban networks of music production Global Networks 12 (4) 446-466 